\title{
The Impact of Corporate Cash Holding on Stock Price Crash Risk: Evidence from China
}

\author{
Yundi $\mathrm{Gao}^{1, \mathrm{a}, \uparrow, * *}$ and Zihan $\mathrm{Li}^{2, \mathrm{~b}, \uparrow, *}$ \\ ${ }^{1}$ The University of Edinburgh, EH8 9JS, Edinburgh, United Kingdom, s1944606@ed.ac.uk \\ ${ }^{2}$ Lancaster University, LA1 4YW, Lancaster, United Kingdom, liz69@lancaster.ac.uk \\ *Corresponding authorEmail: ${ }^{a}$ s1944606@ed.ac.uk, ${ }^{b}$ liz69@lancaster.ac.uk \\ These authors contributed equally
}

\begin{abstract}
We develop the panel regression model to examine the effect of corporate cash holding on stock price crash risk with data of Chinese listed firms during 2007 to 2018. Based on our results, the corporate cash holding is positively associated with future stock price crash risk. This robustness of results is verified by conducting a series of checks including alternative sample, fixed effects model, and adding omitted control variables. Moreover, the impact of cash holding on stock price crash risk is more pronounced in state-owned enterprises and firms with higher analyst coverage and greater growth. This paper provides support for the agency theory about its effects on stock price crash risk, confirming that the interest conflicts between stockholders and executives do increase the crash risk. In addition, this paper suggests firms cautiously consider their cash holding level and rationally supervise management behavior.
\end{abstract}

Keywords: cash holding, stock price crash risk, agency theory

\section{INTRODUCTION}

Cash holding is essential for any firms, which provides the liquidity of the firm to survive from its operating, financing and investing activities [1]. In financial literature, cash is usually defined as cash and short-term marketable securities or cash equivalents [2, 3]. To investigate the motivation behind firms' cash holding, researchers have proposed three widely accepted theoretical models: trade-off model (transaction costs model) [3], the pecking-order theory (financing hierarchy theory) [4] and the free cash flow theory [5]. Excepted for modelling, there are also four generally accepted motivations behind the cash holding behavior: the transaction motive, precautionary motive, future investment motive and agency motive. The first three terms are closely related to the trade-off model, while the agency motive does not connect to any above models as it is specially used to explain cash holding from the manager perspective.

When cash holding is explained by the trade-off model, there is an optimal level of holding cash behavior to balance the marginal costs and marginal benefits, which relates to the three motivations of a firm $[1,4]$. The transaction motive is that any firm has to hold cash for their operating activities (e.g., raising funds or daily transaction payment) [3 6]. The precautionary motive and future investment motive are both future oriented in case of the emergency of cash reserve rupture. Whereas, the former term focuses on unpredicted expenses and contingencies [7], the latter term puts emphasis on enlarging future capital and investment problems [8]. Based on the above motivations, firms have to balance sales and costs of cash holding to satisfy current needs and preparing for future emergencies. On the one hand, cash holding has its marginal cost, which is the opportunity cost of capital due to low return on liquid assets relative to other investments of the same risk [2, 3]. On the other hand, firms have to reduce the probability of financial distress (keep its marginal benefits of cash holding) by allowing the optimal investment policy for the firm and avoid the costs of increasing external funds or liquidating existing assets. These actions are essential for a firm to maintain its growth.

In the pecking-order theory, the firm will use retained earnings (a form of equity) to finance their investment as a buffer in order to lower asymmetric information costs $[1,2]$. Following the theory, it is very costly for firms to issue new equities due to information asymmetries. 
Therefore, firms chose retained earnings (internal funds) as the primary resource to finance their investment. If the retained earnings are not sufficient, the firms will finance with debt and finally with equities. Following the financing order, debt holders are the earliest group who will get their money back when the corporate goes bankruptcy, while the shareholders come last to share the remaining money. Clearly the distribution order brings conflicts between the stockholders and the firm. Investors are taking risk of non-recovery of principal, i.e., they will not let the firm crash. Conversely, stockholder's attitude can strongly affect the financing efficiency of a firm. Specifically, if investors no longer trust the firm can bring back higher returns or even principal, their withdraws will bring stock price crash risk.

Based above theory, managerial decisions of firms are affected by major stockholders when the firm gathers more external funds from stockholders. In free cash flow theory, the firm can increase the number of assets and the power of making investment decisions by building up cash [5]. Therefore, managers tend to hold more cash to strengthen their control, sometimes even pushing them to embezzle cash for their private interests. The agency motive appears to explain this kind of behavior, which will lead to conflicts and distrusts between stockholders and managers. From the manager's perspective, holding cash can enhance their power and control over the investment decision of the firm, and easily satisfy their private needs [5]. From the perspective of stockholder, cash holding can reduce their transaction costs, prevent the loss of under-investment due to shortage of funds and reduce the firm's cash flow uncertainty to support their living. Hence holding cash is important for their common interests.

Moreover, previous studies have provided the possible economic effect that cash holding might bring to firms. As Jensen's agency theory points out, large cash reserves can increase the agency conflicts between managers and shareholders on account of managerial discretion [5]. Based on the concept, Kim et al. believe that the excess cash holding leads to incomplete disclosures by the manager [9], which will increase investors' perception for the transparency and result in equity price crash risk in the future. Acharya believes that corporate cash holding is positively correlated with credit spreads and long-term defaults [10], which is related to managerial behavior.

Concerning another aspect, many scholars also explore the factors and outcomes that might exacerbate stock price crash risk. Specifically, Kim et al. argue that tax avoidance by managers within a firm increases stock price crash risk [11]. This is ascribed to the fact that tax avoidance by managers complicates the business activities of the firm and makes it more difficult for investors to understand the real situation of the firm. The more tax avoidance, the higher the risk of a stock price crash. Meanwhile, Kim et al also believe that equity incentives are positively associated with stock price crash risk [11]. An and Zhang show that institutional investors with long-term shareholding help to strengthen corporate governance and discourage opportunistic managerial behavior, i.e., reduces synchronization and crash risk of the firm's share price [12]. However, Xu et al. have found that the "herding behavior" of institutional investors will reduce the transparency of corporate information disclosure while increasing stock price crash risk [13]. Other scholars further explore the effect of information intermediation on stock price crash risk. For example, Xu et al. have studied the relationship between analysts' optimism bias and stock price crash risk. According to their investigation, analysts' optimism bias would make it difficult to disclose negative company news to outside investors in a timely manner. Besides, this optimism bias is significantly and positively related to stock price crash risk [14].

Based on previous studies, it is clear that both cash holding and stock price crash risk are important and wellexplored indicators among all economic consequences. However, rarely of literature has mentioned or proven a causal relationship that clearly links these two factors, i.e., our research more contributed in fulfilling this blank area.

We investigate the impact of corporate cash holding on stock price crash risk using collected data on cash holding from Chinese listed firms over the period 2007 to 2018. We find that the corporate cash holding is positively associated with its future stock price crash risk. Our model goes through numbers of robustness checks including alternative sample, fixed effects model, and adding omitted control variables to prove the association is robust. For further analysis, the result shows that the impact of cash holding on stock price crash risk is more pronounced in state-owned enterprises (hereafter, SOEs) and firms with higher analyst coverage and greater growth. This paper helps firms better deal with internal management problems based on the agency theory about its effects on stock price crash risk, emphasizing there exists conflicts of interest between stockholders and management which will increase the crash risk. Therefore, firms should cautiously consider their cash holding level and rationally control internal management behavior.

The reasons why we focus our research on the Chinese market are as follows. First, the Chinese stock market is a representative of developing markets. In other words, the Chinese stock market is relatively vulnerable to external factors, e.g., policies and irrational behavior $[15,16]$. For example, in 2015, Chinese government put forward a series of new strategies and directions to curb the bubble in the real estate industry. However, this led to a large proportion of securities financing and over-thecounter placements, i.e., the leverage ratio surged in a 
short time. The crash happened in the middle of 2015 , during which the Shanghai Composite Index fell by 1,800 points, down nearly $35 \%$ compared to the previous month.

Second, the Chinese government interferes too much with Chinese listed firms, making shareholders more difficult to regulate the internal managers of firms. Unlike other capital markets, Chinese listed firms are characterized by the dominance of state ownership. Xiong has found that the state would supervise and intervene excessively in enterprises to protect its own interests. Usually those intervenes are administrative [17]. For example, the research of Bo and $\mathrm{Wu}$ suggests that SOEs are required to carry a large number of policy burdens that are not entirely profit-oriented. Specifically, it includes promoting economic growth, increasing employment, and maintaining social stability [18]. Such institutional arrangements limit stakeholders' participation and monitoring of the management of Chinese listed firms.

The linkage of interests between executives and shareholders in Chinese listed firms is weaker than in other countries. The compensation of the management of Chinese listed firms is strictly regulated by the government. In 2009, the Ministry of Human Resources and Social Security together with five other departments, stipulated that the annual salary of executives of Chinese firms should not exceed 20 times the average salary of employees. As a result, the incentive effect of compensation contracts on executives is greatly reduced, and executives are less motivated to work hard. Ultimately, Xiong suggests that the linkage of interests between executives and shareholders is weakened [17]. In contrast to Chinese firms, listed firms in other capital markets are subject to less administrative intervention and policy burdens. As a consequence, they are able to control managers' influence on corporate cash flows more easily by designing reasonable compensation contracts and corporate governance models. Given the constraints on Chinese listed firms, there is a greater demand of a clear strategy for corporate to reform in the Chinese market.

Our contribution will be reflected in the following aspects. First, this paper provides a new idea for firms to deliberately determine the level of cash holding. Since too much cash holding will lead to the emptying behavior of managers, firms need to carefully determine the cash holding level and properly supervise the management. Second, we enrich the field of factors that affect stock price crash risk. Expect for factors such as analyst optimism bias and cash flow manipulation, we find that cash holding also has an impact on stock price crash risk of the firm. Third, we work out a specific relationship between cash holding and stock price crash risk, which paves a path to the agency theory and a reference to other emerging markets.
The structure of this paper is organized as follows: In section 2, we develop the hypothesis based on the previous theories, especially from the agency theory and the prediction motive. Section 3 describes the research design, including sample construction, model specification, and variable measurement. The empirical results and their analysis are explained in section 4. Section 5 includes robustness checks. Sections 6 and 7 provide further analysis and the conclusion.

\section{HYPOTHESIS DEVELOPMENT}

Stock price crash risk refers to the possibility of a sudden and sharp fall in stock prices or the broad market index without any forewarning. The existing literature explains the bad news hoarding theory that triggers stock price crash risk mainly from the information transparency as well as the agency perspective. From the information transparency perspective, Bleck and Liu [19] and Pan et al. [20] have explained that the opaque information of the firm will lead to the inability of outside investors to detect negative NPV investment projects in a timely manner. Since they lack the control to force the manager to abandon their investment in the project, a negative NPV project will lead to a loss for the company. Thus, it increases the likelihood of a future crash in the stock price of the firm. From the perspective of the agency, Jin and Myers show in their findings that internal managers strategically hide and delay the disclosure of bad news of the firm in order to gain self-interests (e.g., job promotion and salary maximization) [21]. Hutton et al. believe that the bad news will gradually accumulate as the business cycle continues. Once the accumulation overtakes a critical level, the bad news will be released in a concentrated manner, eventually leading to the crash of the stock price [22]

Theoretically, there are two different views on the effect of cash holding and stock price crash risk. One view is to combine the three following theories from the manager perspective, which supports that cash holding is positively related to stock price crash risk. Firstly, as the first type agency theory stated, a firm with sufficient cash holding will drive managers to maximize their own interests at the cost of damaging stockholders' interests (e.g., illegal cash diversion or overinvestment) due to the "inconsistent utility function effects" between stockholders and managers [5]. Consequently, to cover up those behavior, managers might whitewash a firm's financial statement to conceal the truth from shareholders based no bad news hidden theory.

Another motivation comes from experienced managers who want to prove their corporate proficiency or being overconfidence to make risky investment decisions [23, 24], which is also harmful for corporate stability. According to transparency theory, the opacity information caused by management behavior will lead to delayed reflections for investors to withdraw from 
deficient project, causing huge loss and increasing firm's future stock price crash risk [25]. Once the project falls and the bad news flow into the market, the panic will spread among investors [9] owing to the herd behavior [15], resulting in a more serious stock market crash. Hence, we assume the improper management behaviors cause positive relation between cash holding and stock price crash risk.

The other view is that there exists a negative impact of cash holding on stock price crash risk. Specifically, there are two arguments supporting this opinion. From the perspective of precautionary motivation, firms increase the level of their cash holding to hedge against the uncertainty created by the macroeconomy. Gertler and Gilchrist have found that monetary tightening squeezes corporate cash [26]. In that case, firms tend to borrow in order to smooth out the declining cash flow capacity. It is noticeable that legal protection for investors is unsound in China because the financial market has problems that are not yet well developed as well as information asymmetry. As a result, Chinese firms rely heavily on retained profits. Based on this premise, Yang et al. find that financial constraints and credit supply volatility will largely affect the investment behavior of Chinese firms [27]. Specifically, Yang et al. also suggests that the financial constraints on firms result from the monetary policy will adversely affect their investment if their cash holding is unable to finance all the projects that can bring profit opportunities to the firm [27]. To prevent this, Almeida et al. [28] and Opler et al. [3] indicated that firms increase their cash holding by borrowing, i.e., they can protect themselves from the risk of future underinvestment and unpredictable cash flow fluctuations. The more adequate cash reserves a firm has, the better it is protected from adverse monetary policy shocks. Additionally, Duchin et al. found out that these firms with adequate cash can do buy-back to deal with the problem and it is more likely for them to finance at a lower cost with faster speed [29]. It follows that firms with higher levels of cash flow can better cope with cash flow volatility and shocks (e.g., monetary tightening), insulating the firm from the risk of a sharp decline in cash flow that will prevent turnover and reduce the likelihood of a stock price crash.

Another opposite explanation of the second type of agency theory is between the controlling shareholders and the minority shareholders. Following Johnson, the controlling shareholders have a positive impact on the cash holding strategy [30]. On the one hand, the controlling shareholders control operating revenue distribution, with a probability of asset misappropriation. On the other hand, they can better supervise management behaviors to reduce the first type of agency problem. The higher the ownership concentration, the better consistency of the interests between the controlling shareholders and corporation [30]. Therefore, shareholders are motivated to supervise the management and seek greater interests for the company by taking advantage of their own superior resources [31]. Furthermore, shareholders can maintain a low level of managerial operation, which alleviates the first type of agency problems [32]. For example, when the firm is faced with external crises (e.g., cash flow shortage or financing difficulties), the controlling shareholders are likely to provide additional financial resources to relieve cash holding pressure (e.g., increasing investment, borrowing credits and adding leverage [33]). Moreover, the more shares held by shareholders, the stronger the butler supervision will be, which will alleviate the agent motivation and optimize the cash holding level. As a result, stock price crash risk will not happen even if cash holding increases.

Based on the above discussions, we propose the following competing hypotheses concerning the impact of corporate cash holding on stock price crash risk.

H1a: Corporate cash holding can decrease future stock price crash risk, ceteris paribus.

H1b: Corporate cash holding can exacerbate future stock price crash risk, ceteris paribus.

\section{RESEARCH DESIGN}

\subsection{Construction of sample}

The sample in this study initially comprises all firms listed on the Shanghai Stock Exchange (SHSE) and the Shenzhen Stock Exchange (SZSE) from 2007 to 2018. Following Xu et al. [13], we exclude financial firms (e.g., banks, insurance firms, and investment trusts) as they account and report under rules, and tend to have a capital structure, different from other firms. Meanwhile, we also drop those observations with fewer than 30 trading weeks of stock return data in a fiscal year. Finally, a usable sample of 19,290 firm-year observations is obtained. The financial data used in this study are obtained from China Stock Market Accounting Research (CSMAR) database.

\subsection{Model}

The hypotheses to be tested are that stock price crash risk is a function of cash holding and other control variables. The basic empirical model employed is:

$$
\begin{aligned}
& N_{C S K E W_{t+1}}\left(\operatorname{DUVOL}_{t+1}\right) \\
& =\beta_{0}+\beta_{0} \operatorname{Cash}_{t} \\
& +\sum_{q=2}^{m} \beta_{q}\left(\text { qth Controlvariable } \text { Con }_{t}\right)+\varepsilon_{\mathrm{t}}
\end{aligned}
$$

where $\beta_{1}$ represents regression coefficients; $\varepsilon_{t}$ is an error term; and control variables contain $N C S K E W_{t}$, Ret $_{t}$,

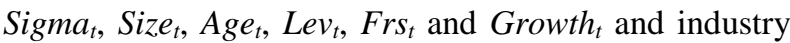
dummies. $N C S K E W_{t}$ and $D U V O L_{t}$ measure stock price 
crash risk, whereas Cash $_{t}$ represents the amount of cash holding of a given firm. A negative (positive) $\beta_{1}$ suggests that $\mathrm{Cash}_{t}$ tends to decrease (increase) future stock price crash risk. All variables that will be used are concluded in Table 8 and all continuous variables are winsorized at $1 \%$ at both tails.

\subsection{Variables}

\subsubsection{Dependent variable}

Following Kim et al. [9] and $\mathrm{Xu}$ et al. [13], we use two separate measures of stock price crash risk: negative skewness coefficient (NCSKWE) and upward and downward volatility of returns (DUVOL).

First, Eq. (2) is utilized to regress firm $i$ 's specific earnings data at week $t$ :

$$
\begin{aligned}
R_{i, t}=\alpha+\beta_{1} R_{m, t} & +\beta_{2} R_{m, t-1}+\beta_{3} R_{m, t} \\
& +\beta_{4} R_{m, t+1}+\beta_{5} R_{m, t+2} \\
& +\varepsilon_{i, t}
\end{aligned}
$$

where $R_{i, t}$ is the return of firm $i$ in week $t$ considering reinvestment of cash dividends, and $R_{m, t}$ is the average return of all firms in the stock market weighted by market capitalization outstanding in week $t$ corresponding to firm $i$. In addition, the lagged and ahead terms of market return are included in Eq. (2) to adjust for the effect of non-synchronous stock trading. Second, we construct firm-specific weekly earnings $W_{i, t}=\ln \left(1+\varepsilon_{i, t}\right)$ based on the regression residuals of Eq. (2). Finally, Eqs. (3) and (4) are used to calculate the negative return skewness coefficient (NCSKEW) and the upward and downward earnings volatility (DUVOL), respectively, which serve as a measure of the firm's stock price crash risk.

$$
\begin{array}{r}
\operatorname{NCSKEW}_{i, t}=-[ \\
/\left[(n-1)^{3 / 2} \sum W_{i, t}^{3}\right] \\
\left.-2)\left(\sum W_{i, t}^{2}\right)^{3 / 2}\right]
\end{array}
$$

where $n$ is the total number of trading weeks for stock $i$ in year $t$. A larger value of NCSKEW indicates a more severe negative skewness coefficient and higher stock price crash risk.

$$
\begin{aligned}
& \operatorname{DUVOL}_{i, t}=\log \{ {\left[\left(n_{u}-1\right) \sum_{\text {Down }} W_{i, t}^{2}\right] } \\
&\left./\left[\left(n_{d}-1\right) \sum_{U p} W_{i, t}^{2}\right]\right\}
\end{aligned}
$$

where $n_{u}$ is the number of up weeks and $n_{d}$ is the number of down weeks. A larger value of DUVOL means that the distribution of stock returns tends to be more left-skewed and the risk of a crash is higher.

\subsubsection{Test variable}

The test variable $\mathrm{Cash}_{t}$ means the amount of cash holding of a given firm. To standardize the result, Cash $_{t}$ is calculated as the ratio of total cash and equivalent items to total assets of the firm.

\subsubsection{Control variables}

For endogeneity, a number of variables are controlled that have been previously studied as having the potential to affect stock price crash risk. The first variable is $N C S K W E_{t+1}$, which means the negative skewness coefficient of firm $i$ at a specific year $t+1$. Chen et al. find that firms with higher value of it will be more likely to suffer from the stock prick crash risk [34]. The Ret $_{t}$ is past returns of the firm, which is calculated by using the arithmetic average of weekly returns in year $t$ of a specific firm. Chen et al. also shows that stocks with higher $\operatorname{Ret}_{t}$ are more likely to collapse [34]. As Chen et al. state that volatility of stocks is positively correlated with stock price crash risk, we also add the variable Sigma $_{t}$ into our consideration, which is defined as the standard deviation of the weekly returns of a specific firm in fiscal year $t$ [34]. Hutton et al. suggest a positive relationship between the size of a corporation and stock price crash risk [22]. As a result, the variable Size $e_{t}$ needs to be controlled. In addition, taking the financial leverage $L e v_{t}$ into account, it is equal to the value of the book value of total debt divided by the book value of total assets. Besides, other variables are also controlled, e.g., the growth rate of the company's main business $\left(\right.$ Growt $\left._{t}\right)$, the natural logarithm of the (1+age) of the firm $\left(\right.$ Age $\left._{t}\right)$ and the shareholding ratio of the company's largest shareholder $(F r s)$.

\section{EMPIRICAL ANALYSIS}

\subsection{Descriptive statistics}

Table 1 provides descriptive statistics for the variables of this paper. The means of crash risk measures, $N_{C S K E W_{t+1}}$ and DUVOL $L_{t+1}$, are -0.274 and -0.182 , respectively. Their medians are -0.236 and -0.181 accordingly while the standard deviations of them are 0.683 and 0.469 . These estimations are close to the results of Bai et al. [35], Guariglia et al. [36], and Xu et $a l$. [37]. The mean of cash measure $\left(\mathrm{Cash}_{t}\right)$ is 0.210 and its standard deviation is 0.229. The minimum of $\mathrm{Cash}_{t}$ is 0.010 , while its maximum is 1.381 , which is much higher than the minimum, showing that the corporate cash holding levels among different firms vary a lot. In addition, the standard deviations of them are 0.683 and 0.469 . Overall, it is found that there is a huge difference among corporations from the perspectives of crash risk and cash holding. 
Table 1 Descriptive statistics.

\begin{tabular}{lcccccc}
\hline Variable & $\mathrm{N}$ & Mean & Std. dev. & Minimum & Median & Maximum \\
\hline NCSKEW $_{t+1}$ & 19,290 & -0.274 & 0.683 & -2.306 & -0.236 & 1.456 \\
DUVOL $_{t+1}$ & 19,290 & -0.182 & 0.469 & -1.306 & -0.181 & 0.963 \\
Cash $_{t}$ & 19,290 & 0.210 & 0.229 & 0.010 & 0.137 & 1.381 \\
Ret $_{t}$ & 19,290 & -0.001 & 0.001 & -0.005 & -0.001 & 0.000 \\
Sigma $_{t}$ & 19,290 & 0.048 & 0.018 & 0.017 & 0.046 & 0.104 \\
Size $_{t}$ & 19,290 & 22.080 & 1.304 & 19.480 & 21.910 & 26.000 \\
Lev $_{t}$ & 19,290 & 2.772 & 0.363 & 1.609 & 2.833 & 3.434 \\
Growth $_{t}$ & 19,290 & 0.468 & 0.205 & 0.064 & 0.471 & 0.939 \\
Age $_{t}$ & 19,290 & 0.363 & 0.153 & 0.088 & 0.346 & 0.759 \\
Frs $_{t}$ & 19,290 & 0.206 & 0.518 & -0.574 & 0.118 & 3.701 \\
\hline
\end{tabular}

This table reports descriptive statistics on crash risk, cash holding, and other control variables about Chinese listed corporation from 2007-2018. All variables are defined in Table 8.

\subsection{Correlation Analysis}

We calculated the Spearman correlation coefficient between variables. As part of the data may be normally distributed, Pearson correlation cannot be used. Results from Table 2 shows that $\operatorname{Cash}_{t}$ is significantly and positively correlated with $N C S K E W_{t+1}$ and $D U V O L_{t+1}$, which is consistent with our proposed hypothesis $\boldsymbol{H} \mathbf{1 b}$. In addition, the result also shows relatively low correlations among the independent variables. To avoid the effect of multiple linear regressions on the findings, the VIF values of each variable is calculated. By taking the average of the VIF values of all variables, obtaining a mean VIF value of 5.62. Following the rules of multiple regression models, this value would indicate that this result is not affected by multiple linear regression [38].

\subsection{Univariate analysis}

Table 3 and 4 present the result of the univariate analysis with the key variables as the main focus. We create two groups based on whether stock price crash risk coefficient is greater than -0.182 . The final result shows that the group with a stock price crash risk greater than this value has a higher mean value of cash and vice versa. In addition, the table also shows that the difference between the means of two groups of cash is greater than $5 \%$, which is statistically significant. This indicates that firms with higher cash holding have a greater risk of stock price crash.

\subsection{Multivariate results}

Table 5 illustrates the results obtained from our regression model based on two measures of stock price crash risk. Columns (1) and (2) report the regression results without control variables, while columns (3) and (4) report the results of fixed effect model estimation after introducing our control variables.

Before adding our control variables, coefficients of Cash $_{t}$ are 0.117 and 0.086 in columns (1) and (2) respectively and both are significant at the $1 \%$ level. After introducing control variables, the coefficients of Cash $_{t}$ in columns (3) and (4) are $0.067(t$ value $=2.8)$ and 0.045 ( $t$ value $=2.7)$ respectively, which are still significant at the $1 \%$ level. In addition, the Adjusted $R^{2}$ of columns (3) and (4) are 0.064 and 0.068 respectively, showing the goodness of fit. The result shows that the more cash a firm holds, the higher the risk of its stock price crashing. As a result, the $\boldsymbol{H} \boldsymbol{1 b}$ is primarily confirmed.

The coefficients of the control variables have consistency with prior studies of $\mathrm{Xu}$ et al. [34]. Generally, firms with higher returns, smaller size, younger listed age and higher growth rate are relative to higher future stock price crash risk

Table 2 Correlation analysis of all the parameters.

\begin{tabular}{|c|c|c|c|c|c|c|c|c|c|c|}
\hline & $N C S K E W_{t+1}$ & $D U V O L_{t+1}$ & Cash $_{t}$ & $\operatorname{Ret}_{t}$ & Sigma $_{t}$ & Size $_{t}$ & $A g e_{t}$ & Lev $_{t}$ & $F r s_{t}$ & Growth $_{t}$ \\
\hline$N C S K E W_{t+1}$ & 1 & $0.884 * * *$ & $0.054 * * *$ & $\begin{array}{l}- \\
0.029 * * *\end{array}$ & $0.030 * * *$ & $\begin{array}{l}- \\
0.117 * * *\end{array}$ & $\begin{array}{l}- \\
0.054 * * *\end{array}$ & $\begin{array}{l}- \\
0.057 * * *\end{array}$ & $\begin{array}{l} \\
0.033 * * *\end{array}$ & $0.031 * * *$ \\
\hline$D U V O L_{t+1}$ & $0.875 * * *$ & 1 & $0.055^{* * * *}$ & $-\overline{0.024 * * *}$ & $0.024 * * *$ & $-\overline{0.126 * * *}$ & $-\overline{0.055 * * *}$ & $-\overline{0.064 * * *}$ & $-\overline{0.032 * * *}$ & $0.030 * * *$ \\
\hline Cash $_{t}$ & $0.052 * * *$ & $0.056^{* * *}$ & 1 & $0.042^{* * *}$ & $0.042 * * *$ & $0.195^{* * *}$ & $0.077 * * *$ & $0.340 * * *$ & -0.000 & $0.054 * * *$ \\
\hline $\operatorname{Ret}_{t}$ & -0.011 & -0.003 & $-0.014 * *$ & 1 & 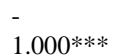 & $0.330 * * *$ & $0.149 * * *$ & 0.009 & $0.045^{* * *}$ & $0.035 * * *$ \\
\hline
\end{tabular}




\begin{tabular}{|c|c|c|c|c|c|c|c|c|c|c|}
\hline Sigma $_{t}$ & $0.025 * * *$ & $0.015^{* *}$ & $0.025 * * *$ & $\overline{-}-975 * * *$ & 1 & $\overline{0.332 * * *}$ & $\overline{0.149 * * *}$ & -0.010 & $\overline{0.046 * * *}$ & 0.036 *** \\
\hline Size $_{t}$ & $-0.115 * * *$ & $-0.125^{* * *}$ & $\overline{0.198 * * *}$ & $0.269 * * *$ & $\overline{-} \mathbf{0 . 3 1 2 * * *}$ & 1 & $0.198 * * *$ & $0.408 * * *$ & $0.199 * * *$ & 0.009 \\
\hline $\mathrm{Age}_{t}$ & $-0.054 * * *$ & $-0.054 * * *$ & $\overline{0}-117 * * *$ & $0.088 * * *$ & $\overline{0}-110 * * *$ & $0.168 * * *$ & 1 & $0.093 * * *$ & $\overline{0}-156^{* * *}$ & $\overline{0} .101 * * *$ \\
\hline Lev $_{t}$ & $-0.051 * * *$ & $-0.061 * * *$ & $-\overline{0.346 * * *}$ & 0.001 & -0.005 & $0.399 * * *$ & $0.114 * * *$ & 1 & $0.041^{* * * *}$ & $0.034 * * *$ \\
\hline$F r s_{t}$ & $-0.034 * * *$ & $-0.034 * * *$ & $0.030 * * *$ & $0.039 * * *$ & $-\overline{0.049 * * *}$ & $0.234 * * *$ & $-\overline{0.158 * * *}$ & $0.039 * * *$ & 1 & 0.011 \\
\hline Growth $_{t}$ & 0.017 ** & $0.013 *$ & $0.012 *$ & 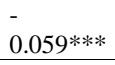 & $0.068^{* * * *}$ & -0.005 & $0.026 * * *$ & $0.056 * * *$ & $0.033 * * *$ & 1 \\
\hline
\end{tabular}

Notes: $*$ Indicates significance at the $10 \%$ level (two-tailed), $* *$ indicates significance at the $5 \%$ level (two-tailed), $* * *$ indicates significance at the $1 \%$ level (two-tailed).

The table shows the correlation efficient of Cash $_{t}$ together with $N C S K E W_{t+1}$ and $D U V O L_{t+1}$. The result shows that corporate cash holding is significantly and positively correlated with stock price crash risk.

Table 3 Univariate analysis.

\begin{tabular}{lcccccc}
\hline Variable & G1(0) & Mean1 & G2(1) & Mean2 & MeanDiff & t-Value \\
\hline Cash $_{t}$ & 9132 & 0.200 & 10158 & 0.220 & 0.0210 & $6.296^{* * *}$ \\
\hline
\end{tabular}

Notes: $* * *$ Indicates significance at the $1 \%$ level (two-tailed).

Table 3 indicates the value of the variable $\mathrm{Cash}_{t}$ when stock price crash risk indicator $N C S K W E_{t+1}$ is greater (1) and less $(0)$ than the mean value.

Table 4 Univariate analysis.

\begin{tabular}{lcccccc}
\hline Variable & G1(0) & Mean1 & G2(1) & Mean2 & MeanDiff & t-Value \\
& & & & & & \\
\hline Cash $_{t}$ & 9620 & 0.200 & 9670 & 0.221 & 0.0210 & $6.450^{* * * *}$
\end{tabular}

Notes: $* * *$ Indicates significance at the $1 \%$ level (twotailed)

Table 4 indicates the values of the variable $\operatorname{Cash}_{t}$ when stock price crash risk indicator $D U V O L_{t+1}$ is greater (1) and less (0) than the mean value.

\section{ROBUSTNESS CHECKS}

In this session, we perform several robustness checks to examine the sensitivity of our results, including the fixed effects model, alternative variables and adding omitted variables. The results are summarized in Table 6.

Considering individual difference of companies that might affect regression results, we apply firm fixed effects model to re-estimate our empirical results based on previous results. Columns (1) and (2) show the coefficients of $\mathrm{Cash}_{t}$ are $0.059(t$ value $=5.08)$ and 0.042 $(t$ value $=5.42)$ respectively, both significant at the $10 \%$ level. Therefore, we affirm that our results are not driven by different firm's unobservable factors.
To avoid the measurement error, we apply monetary fund divided by total assets minus monetary fund as an alternative variable to measure the cash holding level of a given firm, referring to Ref. [35, 40]. In columns (3) and (4) of Table 6 , our results are still significant at the $5 \%$ level, which suggest that our regression results are reliable and robust.

To mitigate the endogeneity caused by omitted control variables, we add a number of possibly omitted variables to model 1, including $\mathrm{SOE}_{t}, \mathrm{Big}_{t}$, Gender ${ }_{t}$,

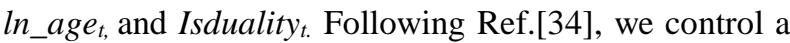
number of corporate governance factors, including $S O E_{t}$ (a dummy variable that equals one if the ultimate controlling shareholder of a listed firm is the state in year $t$ and zero otherwise), Big4 $t_{t}$ (a dummy variable that equals 1 if the firm hires an international Big4 accounting firm in year $t$ and 0 otherwise) [35], Gender $r_{t, \text { (average }}$ gender of executives in the sample firms) [36], ln_age $e_{\text {, }}$ (CEO's management age) [37], Isduality. (a dummy variable that equals one if the CEO and board chairman are the same person, and zero otherwise) [38]. Columns (5) and (6) demonstrate that the coefficients of $\mathrm{Cash}_{t}$ are still significant at the $1 \%$ level (with $t$ value $=2.8$ and $t$ value $=2.7$, respectively) after adding potential omitted variables, which further verifies the robustness of our model.

In conclusion, combined with the above results, the robustness of the main conclusions has been verified.

Table 5 Multivariate results.

\begin{tabular}{|c|c|c|c|c|}
\hline & (1) & (2) & (3) & (4) \\
\hline & $N C S K E W_{t+1}$ & $D U V O L_{t+1}$ & $N C S K E W_{t+1}$ & $D_{U V O L_{t+1}}$ \\
\hline \multirow[t]{2}{*}{ Cash $_{t}$} & $0.117 * * *$ & 0.086 **** & $0.067 * * *$ & $0.045^{* * *}$ \\
\hline & (5.08) & (5.42) & $(2.80)$ & (2.70) \\
\hline$N C S K E W_{t}$ & & & $0.059 * * *$ & $0.031 * * *$ \\
\hline
\end{tabular}




\begin{tabular}{|c|c|c|c|c|}
\hline & & & (7.13) & (5.66) \\
\hline \multirow[t]{2}{*}{$\operatorname{Ret}_{t}$} & & & $111.428^{* * *}$ & $68.138^{* * * *}$ \\
\hline & & & (4.59) & (4.13) \\
\hline \multirow[t]{2}{*}{ Sigma $_{t}$} & & & $7.619 * * *$ & $4.455^{* * * *}$ \\
\hline & & & (5.47) & $(4.71)$ \\
\hline \multirow[t]{2}{*}{ Size $_{t}$} & & & $-0.032 * * *$ & $-0.029 * * *$ \\
\hline & & & $(-6.09)$ & $(-8.05)$ \\
\hline \multirow[t]{2}{*}{$\mathrm{Age}_{t}$} & & & $-0.054 * * *$ & $-0.042 * * *$ \\
\hline & & & $(-3.37)$ & $(-3.85)$ \\
\hline \multirow[t]{2}{*}{ Lev $_{t}$} & & & -0.019 & -0.014 \\
\hline & & & $(-0.63)$ & $(-0.69)$ \\
\hline \multirow[t]{2}{*}{$F r s_{t}$} & & & $-0.063^{*}$ & -0.029 \\
\hline & & & $(-1.67)$ & $(-1.13)$ \\
\hline \multirow[t]{2}{*}{ Growth $_{t}$} & & & 0.007 & 0.003 \\
\hline & & & $(0.73)$ & $(0.38)$ \\
\hline \multirow[t]{2}{*}{ Constant } & $-0.065^{*}$ & $-0.057 * *$ & $0.524 * * *$ & $0.531 * * *$ \\
\hline & $(-1.85)$ & $(-2.10)$ & $(4.00)$ & $(5.85)$ \\
\hline$N$ & 19290 & 19290 & 19290 & 19290 \\
\hline Industry_fixed & YES & YES & YES & YES \\
\hline Year_fixed & YES & YES & YES & YES \\
\hline Adjusted $R^{2}$ & 0.053 & 0.057 & 0.064 & 0.068 \\
\hline
\end{tabular}

Notes: $*$ Indicates significance at the $10 \%$ level (two-tailed), $* *$ indicates significance at the $5 \%$ level (two-tailed), $* * *$ indicates significance at the $1 \%$ level (two-tailed).

This table presents the results of the panel regression model of the impact of cash holding on future stock price crash risk. The dependent variables are NCSKEWt +1 and
DUVOLt+1. The test variable is Casht. All variables are defined in Table 8.

Table 6 Robustness checks.

\begin{tabular}{|c|c|c|c|c|c|c|}
\hline & (1) & (2) & (3) & (4) & (5) & (6) \\
\hline & $N C S K E W_{t+1}$ & $D U V O L_{t+1}$ & $N C S K E W_{t+1}$ & $D U V O L_{t+1}$ & $N C S K E W_{t+1}$ & $D U V O L_{t+1}$ \\
\hline Cash $_{t}$ & $\begin{array}{l}0.059^{*} \\
(1.81)\end{array}$ & $\begin{array}{l}0.042^{*} \\
(1.86)\end{array}$ & & & $\begin{array}{l}0.073 * * * \\
(3.04)\end{array}$ & $\begin{array}{l}0.049 * * * \\
(2.90)\end{array}$ \\
\hline$N C S K E W_{t}$ & $\begin{array}{l}-0.078 * * * \\
(-9.56)\end{array}$ & $\begin{array}{l}-0.053 * * * \\
(-9.46)\end{array}$ & $\begin{array}{l}0.059 * * * \\
(7.13)\end{array}$ & $\begin{array}{l}0.031 * * * \\
(5.67)\end{array}$ & $\begin{array}{l}0.057 * * * \\
(6.91)\end{array}$ & $\begin{array}{l}0.030 \text { *** } \\
(5.48)\end{array}$ \\
\hline $\operatorname{Ret}_{t}$ & $\begin{array}{l}102.792 * * * \\
(4.23)\end{array}$ & $\begin{array}{l}63.835^{* * * *} \\
(3.81)\end{array}$ & $\begin{array}{l}111.111^{* * * *} \\
(4.57)\end{array}$ & $\begin{array}{l}67.946^{* * * *} \\
(4.12)\end{array}$ & $\begin{array}{l}109.885^{* * * *} \\
(4.52)\end{array}$ & $\begin{array}{l}67.241 \text { *** } \\
(4.07)\end{array}$ \\
\hline Sigma $_{t}$ & $\begin{array}{l}7.324 * * * \\
(5.18)\end{array}$ & $\begin{array}{l}4.422 * * * \\
(4.53)\end{array}$ & $\begin{array}{l}7.596 * * * \\
(5.45)\end{array}$ & $\begin{array}{l}4.441 * * * \\
(4.69)\end{array}$ & $\begin{array}{l}7.455^{* * *} \\
(5.34)\end{array}$ & $\begin{array}{l}4.361 * * * \\
(4.60)\end{array}$ \\
\hline Size $_{t}$ & $\begin{array}{l}-0.013 \\
(-1.11)\end{array}$ & $\begin{array}{l}-0.015^{*} \\
(-1.82)\end{array}$ & $\begin{array}{l}-0.032 * * * \\
(-6.12)\end{array}$ & $\begin{array}{l}-0.029 * * * \\
(-8.07)\end{array}$ & $\begin{array}{l}-0.028 * * * \\
(-4.83)\end{array}$ & $\begin{array}{l}-0.026^{* * *} \\
(-6.82)\end{array}$ \\
\hline $\mathrm{Age}_{t}$ & $\begin{array}{l}-0.120 \\
(-1.53)\end{array}$ & $\begin{array}{l}-0.062 \\
(-1.15)\end{array}$ & $\begin{array}{l}-0.054 * * * \\
(-3.34)\end{array}$ & $\begin{array}{l}-0.042 * * * \\
(-3.82)\end{array}$ & $\begin{array}{l}-0.036 * * \\
(-2.21)\end{array}$ & $\begin{array}{l}-0.032 * * * \\
(-2.82)\end{array}$ \\
\hline Lev $_{t}$ & $\begin{array}{l}0.076 \\
(1.52)\end{array}$ & $\begin{array}{l}0.049 \\
(1.43)\end{array}$ & $\begin{array}{l}-0.025 \\
(-0.81)\end{array}$ & $\begin{array}{l}-0.018 \\
(-0.90)\end{array}$ & $\begin{array}{l}-0.000 \\
(-0.01)\end{array}$ & $\begin{array}{l}-0.003 \\
(-0.15)\end{array}$ \\
\hline$F r s_{t}$ & $\begin{array}{l}-0.109 \\
(-1.37)\end{array}$ & $\begin{array}{l}-0.055 \\
(-1.01)\end{array}$ & $\begin{array}{l}-0.062 * \\
(-1.66)\end{array}$ & $\begin{array}{l}-0.028 \\
(-1.12)\end{array}$ & $\begin{array}{l}-0.031 \\
(-0.83)\end{array}$ & $\begin{array}{l}-0.010 \\
(-0.39)\end{array}$ \\
\hline Growth $_{t}$ & $\begin{array}{l}-0.010 \\
(-1.00)\end{array}$ & $\begin{array}{l}-0.006 \\
(-0.88)\end{array}$ & $\begin{array}{l}0.007 \\
(0.73)\end{array}$ & $\begin{array}{l}0.003 \\
(0.39)\end{array}$ & $\begin{array}{l}0.004 \\
(0.37)\end{array}$ & $\begin{array}{l}0.001 \\
(0.09)\end{array}$ \\
\hline $\operatorname{Cash} 2_{t}$ & & & $\begin{array}{l}0.057 * * * \\
(2.62)\end{array}$ & $\begin{array}{l}0.038 * * \\
(2.45)\end{array}$ & & \\
\hline$S O E_{t}$ & & & & & $\begin{array}{l}-0.061 * * * \\
(-5.17)\end{array}$ & $\begin{array}{l}-0.037 * * * \\
(-4.62)\end{array}$ \\
\hline $\mathrm{Big}_{t}$ & & & & & 0.012 & 0.007 \\
\hline
\end{tabular}




\begin{tabular}{|c|c|c|c|c|c|c|}
\hline \multirow{2}{*}{ Gender $r_{t}$} & & & & & $(0.53)$ & $(0.45)$ \\
\hline & & & & & 0.010 & 0.009 \\
\hline & & & & & $(0.76)$ & $(1.02)$ \\
\hline \multirow[t]{2}{*}{ ln_age $e_{t}$} & & & & & -0.032 & -0.015 \\
\hline & & & & & $(-1.11)$ & $(-0.74)$ \\
\hline \multirow[t]{2}{*}{ Isduality $_{t}$} & & & & & 0.003 & -0.005 \\
\hline & & & & & $(0.07)$ & $(-0.20)$ \\
\hline \multirow[t]{2}{*}{ Constant } & 0.232 & 0.275 & $0.530 * * *$ & $0.535^{* * * *}$ & $0.534 * * *$ & $0.519 * * *$ \\
\hline & $(0.75)$ & $(1.29)$ & $(4.04)$ & $(5.90)$ & $(3.02)$ & (4.33) \\
\hline$N$ & 19290 & 19290 & 19290 & 19290 & 19290 & 19290 \\
\hline Industry_fixed & NO & NO & YES & YES & YES & YES \\
\hline Year_fixed & YES & YES & YES & YES & YES & YES \\
\hline Firm_fixed & YES & YES & NO & NO & NO & NO \\
\hline Adjusted $R^{2}$ & 0.064 & 0.066 & 0.064 & 0.068 & 0.066 & 0.069 \\
\hline
\end{tabular}

Notes: $*$ Indicates significance at the $10 \%$ level (two-tailed), $* *$ indicates significance at the $5 \%$ level (two-tailed), $* * *$ indicates significance at the $1 \%$ level (two-tailed).

It shows the result of three methods, including alternative variables and omitted variables and the fixed effects model, all of which verify that our regression result is reliable and robust.

\section{FURTHER ANALYSIS}

To further investigate the possible influencing factors, this paper predicts that the positive relationship between cash holding and stock price crash risk is more pronounced in firms with weaker monitoring mechanisms. The monitoring mechanisms include the SOE, the growth of the firm's main business, Big4 auditors, and the percentage of external analyst, from which the first two variables are categorized into inner control and the remaining are external supervision variables.

\subsection{The moderating effects of internal evaluation}

The management embezzlement behavior is considered as an endogenous problem for the firm, which is not only defined by the characteristic of state properties, but also affected by the level of cash holding surplus [9].

\subsubsection{SOE}

In China, managers in SOEs might be more willing to engage in cash embezzlement, as their firms have an implicit guarantee from the government to prevent it from stock price crash. As Zhuang pointed out, the administrative phenomenon in SOEs makes it more difficult for firms to control the internal management behavior [40]. In Table 7, the samples are divided into two subsets: the SOEs and the non-SOEs. The estimated coefficient of cash holding in column (1) is 0.097, significant at the 5\% level. Similarly, the coefficient of cash holding in column (2) is 0.063 , significant at $5 \%$ level. This indicates that the effect of cash holding stock price crash risk is more pronounced in SOEs.

\subsubsection{Growth}

The sample is divided into two subsets: the higher growth rate of the firm's main business, and the lower growth rate of the firm's main business. Then, we reestimate model with the two subsets separately. The estimated coefficient of cash holding in column (7) is 0.090 , significant at $5 \%$ level. By contrast, the coefficient of cash holding in column (8) is 0.051 , significant at $10 \%$ level. On this basis, the effect of cash holding on stock price crash risk is more pronounced in firms that have higher growth rate.

\subsection{The moderating effects of external monitoring mechanisms}

External supervision is generally recognized as an essential part to reduce information asymmetry and stock price crash risk. Furthermore, hiring Big4 auditors, and a higher percentage of external analysts are strong demonstrations of exterior regulation. The above factors can effectively control agency problems and restrict manager behaviors. Under this condition, cash holding has a slightly influence on stock price crash risk. On the contrary, the weaker the external constraints, the higher stock price crash risk will be.

\subsubsection{Big 4 auditors}

The samples are divided into two subsets: the firms that appoint Big 4 auditors to provide annual reports auditing service and those not. Subsequently, two subsets are used separately to re-estimate the model. The estimated coefficient of cash holding in column (3) is 0.167 and is not significant. In contrast, the coefficient of cash holding in column (4) is 0.060 , significant at the 5\% level. This indicates that the effect of cash holding on 
future crash risk is more pronounced in firms that do not appoint Big 4 auditors.

\subsubsection{Analyst}

Security analysts' attention to listed corporates reduces the impact of information asymmetry on the risk of stock price crash. Xiao Tusheng et al. found that the more accurate analysts' predictions, the smaller the risk of stock price crash [41]. Kothari et al. believe that analyst coverage contributes to more transparent disclosure, i.e., reduces the crash risk to a certain extent [42]. Therefore, we take analyst into consideration and divide the samples into two subsets by the level of analyst coverage. Then, we re-estimate the model with the two subsets separately. The estimated coefficient of cash holding in column (5) is 0.073 , significant at $5 \%$ level. According to the results, a strong correlation of high analyst coverage and cash holding appears. In fact, the report given by analysts provides more accurate grasp to investors of understanding the company's business prospects, which predicts the uncertainty of future cash flow, i.e., alleviates the risk of stock price crash.

\subsubsection{Institutional investor}

The sample are divided into two subsets: the higher institutional shareholding subset with the shareholding above the median of the same year and industry, and the lower institutional shareholding subset with the shareholding below the median. Then we re-estimate model with the two subsets separately. The results show no impacts and weak relationship of institutional investor proportion at any level of significance. Therefore, we consider it as meaningless external variable and will not affect cash holding level.

Overall, these results bolster our findings and help explain the link between cash holding and stock price crash risk. Cash holding appears to have a greater impact on stock price crash risk in SOEs with higher analyst coverage or greater growth. The results are consistent with our prediction in roles of cash holding in the corporate governance of the insured firms when the monitoring mechanisms of these firms are not effective.

\section{CONCLUSION}

In summary, we discuss the influence of cash holding on stock price crash risk of listed firms based on the sample collecting from Chinese non-financial listed corporations between 2007 and 2018. The result shows a significant positive correlation between the above two variables, which means the higher the level of cash held by a firm, the higher the risk of its future stock price crash. This finding remains robust verified by means of different methods to measure cash holding and stock price crash risk. Further analysis suggests that the effect of cash holding on the risk of stock price crash is greater for SOEs than for non-SOEs. In addition, the effect of cash holding on stock price crash risk is more significant in firms with higher analyst coverage and greater firm growth.

The findings of this paper have certain theoretical and practical implications. First, this paper provides a new sight for firms to deliberately determine the level of cash holding. Since too much cash holding will lead to the empty behavior of managers, firms need to carefully determine the cash holding level and properly supervise the management. Second, the field of factors that influence stock price crash risk has been enriched. Expect for factors such as analyst optimism bias and cash flow manipulation, it has been found that cash holding also has an impact on stock price crash risk of the firm. Third, this paper works out a specific relationship between cash holding and stock price crash risk, which provides further support to the agency theory and a reference to other emerging markets.

Table 7 Heterogeneity test.

\begin{tabular}{lllllllll}
\hline & $(1)$ & $(2)$ & $(3)$ & $(4)$ & $(5)$ & $(6)$ & $(7)$ & $(8)$ \\
& SOE & NON SOE & Big4 & NON Big4 & $\begin{array}{l}\text { High } \\
\text { Analyst }\end{array}$ & $\begin{array}{l}\text { Low } \\
\text { Analyst }\end{array}$ & $\begin{array}{l}\text { High } \\
\text { Growth }\end{array}$ & $\begin{array}{l}\text { Low } \\
\text { Growth }\end{array}$ \\
\hline Cash $_{t}$ & $0.097^{* *}$ & $0.063^{* *}$ & 0.167 & $0.060^{* *}$ & $0.073^{* *}$ & 0.012 & $0.090^{* *}$ & $0.051^{*}$ \\
& $(2.56)$ & $(2.07)$ & $(1.62)$ & $(2.44)$ & $(2.32)$ & $(0.33)$ & $(2.27)$ & $(1.80)$ \\
Ret $_{t}$ & $100.551^{* * *}$ & $127.904^{* * *}$ & $221.884^{* *}$ & $108.575^{* * *}$ & $125.964^{* * *}$ & $78.523^{* *}$ & $153.389^{* * *}$ & $80.690^{* * *}$ \\
& $(2.87)$ & $(3.71)$ & $(1.99)$ & $(4.34)$ & $(3.57)$ & $(2.35)$ & $(3.73)$ & $(2.72)$ \\
Sigma $_{t}$ & $6.404^{* * *}$ & $8.886^{* * *}$ & $12.818^{* *}$ & $7.426^{* * *}$ & $8.215^{* * *}$ & $5.766^{* * *}$ & $9.326^{* * *}$ & $6.269^{* * *}$ \\
& $(3.25)$ & $(4.38)$ & $(2.28)$ & $(5.14)$ & $(4.16)$ & $(2.96)$ & $(3.91)$ & $(3.71)$ \\
Size $_{t}$ & $-0.024^{* * *}$ & $-0.032^{* * *}$ & 0.007 & $-0.036^{* * *}$ & $-0.039^{* * *}$ & $-0.077^{* * *}$ & $-0.014^{*}$ & $-0.043^{* * *}$ \\
& $(-3.50)$ & $(-3.80)$ & $(0.39)$ & $(-5.94)$ & $(-5.31)$ & $(-8.56)$ & $(-1.68)$ & $(-6.71)$ \\
Age $_{t}$ & -0.003 & $-0.050^{* *}$ & 0.092 & $-0.065^{* * *}$ & -0.019 & $-0.056^{* *}$ & $-0.047^{* *}$ & $-0.050^{* *}$ \\
& $(-0.10)$ & $(-2.54)$ & $(1.49)$ & $(-3.83)$ & $(-0.90)$ & $(-2.23)$ & $(-1.95)$ & $(-2.37)$ \\
Lev $_{t}$ & -0.011 & 0.039 & -0.030 & -0.017 & -0.076 & $0.098^{* *}$ & $-0.090^{* *}$ & 0.017
\end{tabular}




\begin{tabular}{lllllllll} 
& $(-0.27)$ & $(0.88)$ & $(-0.21)$ & $(-0.54)$ & $(-1.61)$ & $(2.45)$ & $(-1.69)$ & $(0.47)$ \\
Frs $t$ & -0.008 & -0.043 & 0.183 & $-0.077^{* *}$ & -0.077 & -0.031 & -0.098 & -0.041 \\
Frowth $_{t}$ & $(-0.15)$ & $(-0.79)$ & $(1.38)$ & $(-1.98)$ & $(-1.57)$ & $(-0.58)$ & $(-1.63)$ & $(-0.90)$ \\
& 0.013 & -0.002 & 0.004 & 0.006 & -0.015 & 0.010 & -0.004 & 0.044 \\
Constant & $(0.94)$ & $(-0.16)$ & $(0.07)$ & $(0.63)$ & $(-0.94)$ & $(0.78)$ & $(-0.31)$ & $(1.21)$ \\
& $0.321^{*}$ & $0.366^{*}$ & $-1.356^{* * *}$ & $0.634^{* * *}$ & $0.635^{* * *}$ & $1.460^{* * *}$ & 0.104 & $0.774^{* * *}$ \\
& $(1.73)$ & $(1.82)$ & $(-2.74)$ & $(4.38)$ & $(3.56)$ & $(6.76)$ & $(0.51)$ & $(4.76)$ \\
\hline$N$ & 9782 & 9508 & 1328 & 17962 & 9610 & 9680 & 6879 & 12411 \\
Industry_fixed & YES & YES & YES & YES & YES & YES & YES & YES \\
Adjusted $R^{2}$ & YES & YES & YES & YES & YES & YES & YES & YES \\
\hline
\end{tabular}

Notes. All variables are defined in Table $8 . *$ Indicates significance at the $10 \%$ level (two-tailed), $* *$ indicates significance at the $5 \%$ level (two-tailed), $* * *$ indicates significance at the $1 \%$ level (two-tailed)

The moderating effects of monitoring mechanisms on stock price crash risk. This table reports the results of moderating effects of monitoring mechanisms on the relationship between future stock price crash risk and cash holding by dividing the full sample into two groups based on these mechanisms when NCSKEW is adopted to measure stock price crash risk. We use four variables to proxy for monitoring mechanisms: the SOEs, the growth of the firm's main business, Big4 auditors, and the percentage of external analysts. The dependent variable NCSKEW is measured over year $t+1$ and defined in model. The test variable is cash holding. Reported in parentheses are t-values based on robust standard errors clustered by both industry and year.

Table 8 Variable definitions.

\begin{tabular}{|c|c|}
\hline \multicolumn{2}{|c|}{ Crash risk variables } \\
\hline NCSKEW $_{t+1}$ & $\begin{array}{l}\text { The negative skewness of firm-specific weekly returns in year } t+1 \text {, calculating by taking the } \\
\text { negative of the third moment of firm-specific weekly returns for each sample year and dividing it } \\
\text { by the standard deviation of firm-specific weekly returns raised to the third power. }\end{array}$ \\
\hline$D U V O L_{t+1}$ & $\begin{array}{l}\text { The down-to-up volatility. For any stock } i \text { in year } t \text {, we separate all the weeks with firm-specific } \\
\text { weekly returns below the annual mean (down weeks) from those with firm-specific weekly } \\
\text { returns above the period mean (up weeks) and compute the standard deviation for each of these } \\
\text { subsamples separately. We then take the log of the ratio of the standard deviation of the down } \\
\text { weeks to the standard deviation of the up weeks. }\end{array}$ \\
\hline \multicolumn{2}{|l|}{ Cash variable } \\
\hline Cash $_{t}$ & $\begin{array}{l}\text { A dummy variable that equals the amount of cash or cash equivalent holding divide total assets of } \\
\text { a firm. }\end{array}$ \\
\hline \multicolumn{2}{|c|}{ Other variables } \\
\hline $\operatorname{Ret}_{t}$ & $\begin{array}{l}\text { The past returns of the firm, which is calculated by using the arithmetic average of weekly returns } \\
\text { in year } t \text { of a specific firm. }\end{array}$ \\
\hline Sigmat & The standard deviation of the weekly returns of a specific firm in fiscal year $t$. \\
\hline Size $_{t}$ & The natural logarithm of total assets of a corporation. \\
\hline$L e v_{t}$ & $\begin{array}{l}\text { The financial leverage of a firm, which is equal to the value of the book value of total debt } \\
\text { divided by the book value of total assets. }\end{array}$ \\
\hline Growth $_{t}$ & The growth rate of a firm's main business. \\
\hline Aget $_{t}$ & The natural logarithm of $(1+$ firm age $)$. \\
\hline$F r s_{t}$ & The shareholding percentage of the largest shareholder. \\
\hline
\end{tabular}

Notes. This table contains the definitions of variables used in our analysis. All continuous variables are winsorized at $1 \%$ at both tails. 


\section{REFERENCES}

[1] Suen, C. M. (2011). The determinants of cash holdings: evidence from dutch listed firms (Master's thesis, University of Twente).

[2] Ferreira, M. A., \& Vilela, A. S. (2004). Why do firms hold cash? Evidence from EMU countries. European financial management, 10(2), 295-319.

[3] Opler, T., Pinkowitz, L., Stulz, R., \& Williamson, R. (1999). The determinants and implications of corporate cash holdings. Journal of financial economics, 52(1), 3-46.

[4] Myers, S. C., \& Majluf, N. S. (1984). Corporate financing and investment decisions when firms have information that investors do not have. Journal of financial economics, 13(2), 187-221.

[5] Jensen, M. C. (1986). Agency costs of free cash flow, corporate finance, and takeovers. The American economic review, 76(2), 323-329.

[6] Ferreira, M. A., Custodio, C., \& Raposo, C. C. (2005). Cash holdings and business conditions. Available at SSRN 608664.

[7] Bates, T. W., Kahle, K. M., \& Stulz, R. M. (2009). Why do US firms hold so much more cash than they used to?. The journal of finance, 64(5), 1985-2021.

[8] Damodaran, A. (2005). Dealing with cash, cross holdings and other non-operating assets: approaches and implications. Cross Holdings and Other NonOperating Assets: Approaches and Implications (September 30, 2005).

[9] Kim, J. B., Li, Y., \& Zhang, L. (2011). Corporate tax avoidance and stock price crash risk: Firm-level analysis. Journal of Financial Economics, 100(3), 639662.

[10] Acharya, V., Davydenko, S. A., \& Strebulaev, I. A. (2012). Cash holdings and credit risk. The Review of Financial Studies, 25(12), 3572-3609.

[11] Kim, J. B., Li, Y., \& Zhang, L. (2011). CFOs versus CEOs: Equity incentives and crashes. Journal of financial economics, 101(3), 713-730.

[12] An, H., \& Zhang, T. (2013). Stock price synchronicity, crash risk, and institutional investors. Journal of Corporate Finance, 21, 1-15.

[13] Xu, N., Yu, S., Yi., Z. (2013). Herd behavior of institutional investors and stock price crash risk. Management World, Issue 7, pp. 31-43.

[14] Xu, N., Jiang, X., Yi, Z., \& Xu, X. (2012). Analysts' Interest Conflicts, Optimism Bias and Stock Price Crash risk [J]. Economic Research, 47(7), 127-140.

[15] Liu, X. D., Liu, C., Liu, S. C., \& Lu, J. J. (2014). Does herd behavior increase stock price volatility?. Systems Engineering-Theory \& Practice, 34(6), 1361-1368.
[16] Hu, J.Y. (2002). An Empirical Analysis of Policy Effect. Policy Efficiency and Policy Market. Economic Theory and Economic Management, pp. 49-53.

[17] Xiong, J. (2015). Nature of property right, stock liquidity and stock price crash risk. Modern Economic Science, 1, 37(1), pp. 66-77, 126-127.

[18] Xianhui, B., \& Liansheng, W. (2009). The Governance Roles of State-owned Controlling and Institutional Investors: A Perspective of Earnings Management [J]. Economic Research Journal, 2, 81-91.

[19] Bleck, A., \& Liu, X. (2007). Market transparency and the accounting regime. Journal of Accounting Research, 45(2), 229-256.

[20] Yue. P., Yueyi, D., \& Chaoqun, L. (2011). Opaque information, analyst concerns and individual stock price crash risk. Journal of Financial Research, Issue 09, pp. 138-151.

[21] Jin, L., \& Myers, S. C. (2006). R2 around the world: New theory and new tests. Journal of financial Economics, 79(2), 257-292.

[22] Hutton, A. P., Marcus, A. J., \& Tehranian, H. (2009). Opaque financial reports, R2, and crash risk. Journal of financial Economics, 94(1), 67-86.

[23] Hao, D., Shi, Y., Zhang, T. (2020). CEO Tenure, Internal Control and Stock Price Crash Risk, Journal of Central University of Finance \& Economics, 8, 45-60.

[24] Herrmann, P., \& Nadkarni, S. (2014). Managing strategic change: The duality of CEO personality. Strategic management journal, 35(9), 1318-1342.

[25] Bleck, A., \& Liu, X. (2007). Market transparency and the accounting regime. Journal of Accounting Research, 45(2), 229-256.

[26] Gertler, M., \& Gilchrist, S. (1994). Monetary policy, business cycles, and the behavior of small manufacturing firms. The Quarterly Journal of Economics, 109(2), 309-340.

[27] Yang, X., Han, L., Li, W., Yin, X., \& Tian, L. (2017). Monetary policy, cash holding and corporate investment: Evidence from China. China Economic Review, 46, 110-122.

[28] Almeida, H., Campello, M., \& Weisbach, M. S. (2004). The cash flow sensitivity of cash. The journal of finance, 59(4), 1777-1804

[29] Johnson, S., La Porta, R., Lopez-de-Silanes, F., \& Shleifer, A. (2000). Tunneling. American economic review, 90(2), 22-27.

[30] Roberts, M. R., \& Michaely, R. (2011). Corporate dividend policies: Lessons from private firms. Available at SSRN 927802 
[31] Li, S., Lu, C. (2018). Family participation, family control and cash holding level. Journal of Central University of Finance and Economics, 5, 46-58.

[32] Xiong, L., Jiang, Y., Lian, L., Yang, L. (2020). Controlling Shareholders' Leverage Increase and Corporate Cash Holding.

[33] Chen, J., Ezzamel, M., \& Cai, Z. (2011). Managerial power theory, tournament theory, and executive pay in China. Journal of corporate finance, 17(4), 1176-1199.

[34] Xu, N., Li, X., Yuan, Q., \& Chan, K. C. (2014). Excess perks and stock price crash risk: Evidence from China. Journal of Corporate Finance, 25, 419-434.

[35] Jiang, F., \& Kim, K. A. (2015). Corporate governance in China: A modern perspective.

[36] Yuan, R., Sun, J., \& Cao, F. (2016). Directors' and officers' liability insurance and stock price crash risk. Journal of Corporate Finance, 37, 173-192.

[37] Li, Y., \& Zeng, Y. (2019). The impact of top executive gender on asset prices: Evidence from stock price crash risk. Journal of Corporate Finance, 58, 528-550.

[38] Andreou, P. C., Louca, C., \& Petrou, A. P. (2017). CEO age and stock price crash risk. Review of Finance, 21(3), 1287-1325.

[39] Chen, X., Huang, Q., \& Zhang, F. (2015). CEO Duality and Stock Price Crash Risk: Evidence from China. Available at SSRN 2688779.

[40] Zhuang, D. S. (2014). The practical direction of patrol supervision reform in the new period. Chinese Party and Government Cadres Forum.

[41] Tusheng, X., Shunlin, S., \& Lu, L. (2017). Information Disclosure Quality and Stock Price Crash Risk: The Mediating Role of Analyst Forecast. Journal of Finance and Economics, 43(02), 109-120.

[42] Kothari, S. P., So, E., \& Verdi, R. (2016). Analysts' forecasts and asset pricing: A survey. Annual Review of Financial Economics, 8, 197-219. 